\title{
AGRICULTURAL POLICIES AMONG ADVISORY AND COOPERATIVE INDICATORS IN JORDAN
}

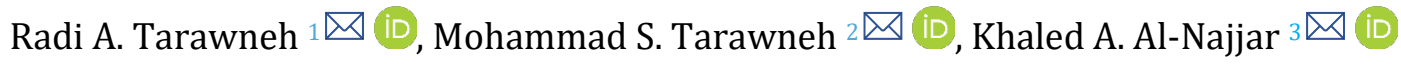 \\ 1,2 Collage of Agriculture, Jerash University, Jerash, Jordan \\ ${ }^{3}$ General Commission for Scientific Agricultural Research, GCSAR, Damascus, Syria
}

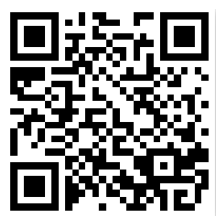

Received 04 January 2022

Accepted 11 February 2022

Published 26 February 2022

CorrespondingAuthor

Khaled A. Al-Najjar,

khnajj2011@yahoo.com

DOI

10.29121/granthaalayah.v10.i2.2022 .4489

Funding: This research received no specific grant from any funding agency in the public, commercial, or not-for-profit sectors.

Copyright: (C) 2022 The Author(s). This is an open access article distributed under the terms of the Creative Commons Attribution License, which permits unrestricted use, distribution, and reproduction in any medium, provided the original author and source are credited.

\section{ABSTRACT}

This study was executed to answer several questions related to agricultural cooperative consultations to improve the livelihoods of farmers in Jordan. Where a questionnaire was conducted through direct personal interviews with the target groups in the Jordan Valley during the year 2021. The study aimed to shed light on the work of cooperative agricultural consultancy and agricultural extension. The study sample included 100 farmers randomly. The data (questionnaires) were analyzed according to SAS (2012). The results were as follows: Agricultural extension should pay more attention to small farmers and the cooperative sector, and agricultural cooperation should be a priority for an extension. In order to overcome the challenges and obstacles of extension work, financial support must be provided for workshops, extension programs, and brochures containing technical information. Attention should be given to agricultural extension cooperation methods through increasing fieldwork days, extension bulletins, home visits, and daily newspapers. Consultative cooperation between government agencies and NGOs was important in supporting farmers' projects. Cooperation between the governmental and non-governmental sectors was linked to priorities of work and the advisory role of NGOs in Jordan.

Keywords: Agricultural Advisory, Extension Priorities, Cooperatives, Jordan

\section{INTRODUCTION}

In Jordan, the first cooperative work began with the issuance of Cooperative Labor Law No. 39 of 1952; Jordanian Cooperative Corporation Law was issued in 1968. In 1997, Cooperation Law No. 18 was issued to organize cooperative work, which had several tasks such as registering cooperative societies, providing advice and guidance, providing technical support, training, and representing the cooperative sector JCC (2021). Agricultural Extension Services were part of the Ministry of Agriculture that was established in 1939. Extension services were institutionalized in 1954 when Agricultural Extension Division was established. Its main functions were to convey results of applied research and to provide advisory services to farmers and rural populations in general regarding agriculture, home economics, and literacy Rimawi and Arabiat (1998). The Jordan Foundation disseminates collaborative thought, directs external support for the benefit of communities, launches income-generating projects to create job opportunities, raises the economic and social level of local communities, uses new technologies, trains for collaborative work, and allocates funding resources for cooperatives JCC (2021).

In Jordan, agricultural cooperatives were less prevalent compared to other 
types, as they constitute $20.7 \%$ of total cooperative work; they need to develop agricultural cooperative work through strengthening agricultural cooperative consultancy JCC (2021). While in Japan, there are 840 very well-organized agricultural cooperatives with balanced planning and effective implementation Gherman et al. (2016).

This study aimed to shed light on the work of the cooperative agricultural consultancy and agricultural extension, as it relied on the analysis of questionnaires and direct meetings with the target groups in order to evaluate and discuss their opinion in Jordan.

\section{MATERIAL AND METHODS 2.1. STUDY QUESTIONS}

This study was conducted in the Jordan Valley to answer several questions related to agricultural consultations:

- What is the work of agricultural cooperative consultancy?

- How is agricultural cooperative consultancy described?

- What is the role of the agricultural advisory cooperative?

These questions are important in evaluating development support for agricultural cooperative consultancy to improve productivity and achieve rural development aimed at improving the livelihoods of smallholder farmers in Jordan.

\subsection{METHODOLOGY}

A survey was conducted according to a questionnaire through personal interviews in the Jordan Valley during 2021. The study sample included 100 farmers at random. The content of the questionnaire was reviewed to verify the validity of the survey questions. The questionnaire consisted of many questions that focused on agricultural production specializations, sectors targeted for cooperative extension work to determine knowledge and its source, priority, obstacles, challenges extension for farmers, preparing extension work, methods, policies, and visions used in extension work, and knowing the role of extension work. In addition, contribution and services of non-governmental organizations and topics of cooperation with the public sector in extension work.

\subsection{STATISTICAL ANALYSIS}

Microsoft Excel was used to review the information in the study questionnaire. Data were analysed according to SAS (2012). Likert scale McLeod (2019), averages, and percentages were used to estimate the methods used in cooperative extension work, extension work priorities, and the rest of the studied indicators, respectively. In addition, correlation values were estimated for most of the studied indicators.

\section{FINDINGS}

Table 1 shows that most of the agricultural disciplines in the studied sample were horticulture sciences (62.3\%) and those farmers had knowledge of extension services $(82.0 \%)$ coming from extension visits $(95.1 \%)$ and that most of them were within rural women sector (57.4\%). Services were implemented within the indicative plans (55.7\%). Most agricultural consultations came within the framework of a regular relationship between public and private cooperatives (35.6\%) through participation methods that included training (54.2\%) and 
scientific seminars (41.0\%). As for the advisory services for NGOs, it was through associations (91.2\%), according to the advisory categories with agricultural cooperatives (69.7\%). On the other hand, farmers face advisory obstacles related to regulations and financial support (85.2\%), and lack of professional advisors and financial support $(90.2 \%)$ presents challenges for agricultural cooperative consulting.

\begin{tabular}{|c|c|c|c|c|c|c|}
\hline VAR. & AS. & (\%) & TS. & $(\%)$ & OFC. & (\%) \\
\hline \multirow[t]{6}{*}{ CAL. } & $\begin{array}{l}\text { - Horticultural } \\
\text { Sciences }\end{array}$ & 62.3 & - Rural Women & 57.4 & $\begin{array}{c}\text { - Regulations } \\
\text { and Financial } \\
\text { Support }\end{array}$ & 85.2 \\
\hline & $\begin{array}{l}\text { - Animal } \\
\text { Production }\end{array}$ & 21.3 & - Rural Youth & 21.3 & - Regulations & 11.5 \\
\hline & $\begin{array}{l}\text { - Agricultural } \\
\text { Economy }\end{array}$ & 6.6 & - Investors & 13.1 & $\begin{array}{l}\text { - Financial } \\
\text { Support }\end{array}$ & 3.3 \\
\hline & $\begin{array}{l}\text { - Agribusiness } \\
\text { management }\end{array}$ & 3.3 & - Small Farmers & 6.6 & & \\
\hline & $\begin{array}{l}\text { - General } \\
\text { Specialty }\end{array}$ & 3.3 & $\begin{array}{l}\text { - Cooperative } \\
\text { Associations }\end{array}$ & 1.6 & & \\
\hline & $\begin{array}{c}\text { - Plant } \\
\text { Protection }\end{array}$ & 3.3 & & & & \\
\hline VAR. & AKS. & $(\%)$ & EAK. & $(\%)$ & CCW. & $(\%)$ \\
\hline \multirow[t]{3}{*}{ CAL. } & $\begin{array}{l}\text { - Agricultural } \\
\text { extension visits }\end{array}$ & 95.1 & - Yes & 82.0 & - By Plans & 55.7 \\
\hline & $\begin{array}{l}\text { - Agricultural } \\
\text { extension } \\
\text { bulletins }\end{array}$ & 3.3 & - No & 3.3 & - By Programs & 18 \\
\hline & & & - Missing values & 14.7 & - Missing values & 26.2 \\
\hline VAR. & ACA. & $(\%)$ & CCS. through & $(\%)$ & CFC. & $(\%)$ \\
\hline \multirow[t]{4}{*}{ CAL. } & $\begin{array}{l}\text { - Regulating } \\
\text { relationship } \\
\text { between public } \\
\text { and private } \\
\text { cooperatives }\end{array}$ & 35.6 & $\begin{array}{l}\text { - Training of } \\
\text { Agricultural Advisory } \\
\text { to Agents }\end{array}$ & 54.2 & $\begin{array}{l}\text { - Lack of } \\
\text { Specialized } \\
\text { Advisory } \\
\text { Agents and } \\
\text { Financial } \\
\text { Support }\end{array}$ & 90.2 \\
\hline & $\begin{array}{l}\text { - Cooperative } \\
\text { Legislation }\end{array}$ & 32.3 & $\begin{array}{l}\text { - Implementation of } \\
\text { Advisory to } \\
\text { Cooperative Societies }\end{array}$ & 27.1 & $\begin{array}{l}\text { - Lack of } \\
\text { Specialized } \\
\text { Advisory } \\
\text { Agents }\end{array}$ & 6.6 \\
\hline & $\begin{array}{l}\text { - Specific } \\
\text { Cooperative } \\
\text { Unions }\end{array}$ & 16.9 & $\begin{array}{c}\text { - Implementation of } \\
\text { Advisory Activities to } \\
\text { Farmers }\end{array}$ & 10.4 & $\begin{array}{l}\text { - Financial } \\
\text { Support }\end{array}$ & 3.3 \\
\hline & $\begin{array}{c}\text { - Cooperative } \\
\text { Societies }\end{array}$ & 10.2 & $\begin{array}{c}\text { - Provide of } \\
\text { Technical Information }\end{array}$ & 8.3 & & \\
\hline VAR. & PPO. & (\%) & NAS. through & $(\%)$ & NAC. & (\%) \\
\hline \multirow[t]{3}{*}{ CAL. } & - Seminars & 41 & - Associations & 91.2 & - Cooperatives & 69.7 \\
\hline & - Conferences & 32.8 & - Projects & 3.5 & - Small Farmers & 27 \\
\hline & - Workshops & 26.2 & & & - Big Farmers & 3.3 \\
\hline
\end{tabular}

VAR: Variables, CAL: Classes, AS.: Agricultural Specialization, TS: Target Sectors, OFC: Obstacles Facing consulting, AKS: Agricultural Knowledge Source, EAK: Extension Agricultural Knowledge, CCW: Cooperative Consulting Work, ACA: Agricultural Cooperative Advisory, CCS: Collaborative Consulting Sharing, CFC: Challenges Facing consulting, PPO: Public-Private Consulting, NAS: NGOs Advisory Services, NAC: NG's Advisory Categories. 
The Agricultural specializations of plant protection, crop production, and animal production came among priorities of agricultural extension work followed by water and irrigation, environment, and agricultural marketing, while agricultural cooperation ranked last according to Figure 1.

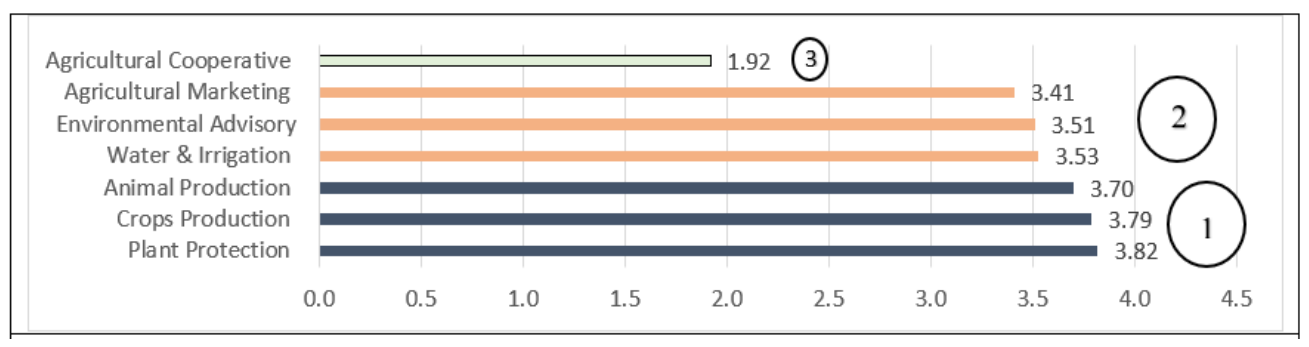

Figure 1 Average priorities of agricultural extension work according to agricultural specialization in Jordan

Figure 2 found that field visits, Agricultural advisory meetings, field agricultural advisory, and farmers' field schools are among the methods that are always used in agricultural extension, while field days and agricultural advisory brochures are sometimes used, and home visits and newspapers are rarely.

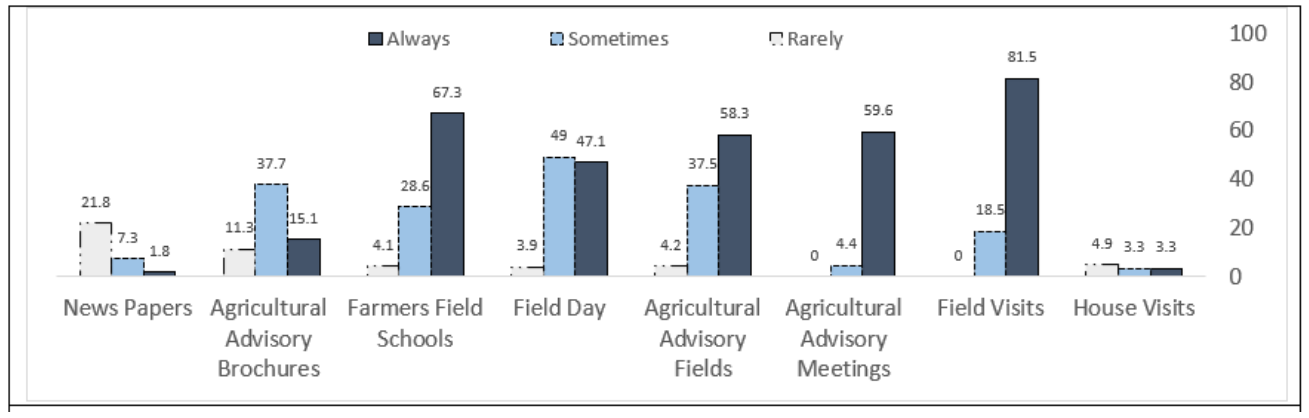

Figure 2 Consultation working methods used in cooperative agriculture in Jordan

Collaborative consulting policies and insights play a full role (100\%) in agricultural extension cooperation. The advisory role of NGOs at work plays a lesser role than government agencies that amounted to only (10\%). The cooperation between the public and private sectors was (3.3\%) according to the studied sample as illustrated in Figure 3.

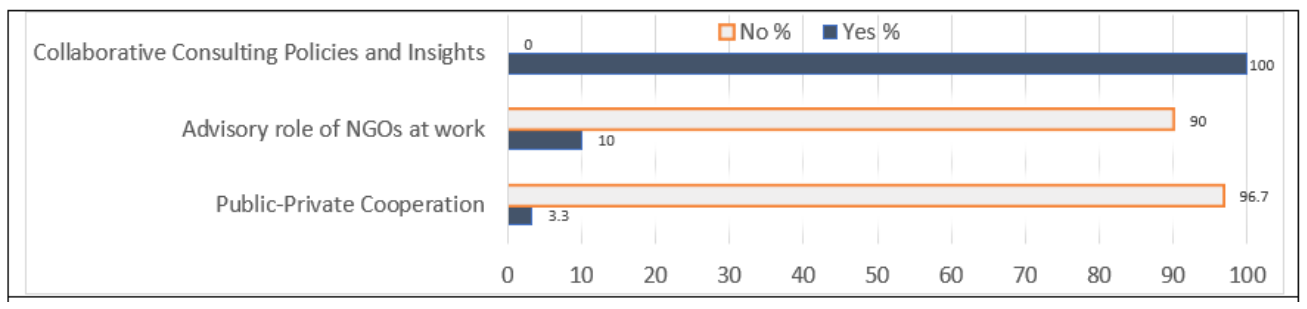

Figure 3 Displays agricultural cooperative consultancy systems in Jordan 
Table 2 displays that correlation values between most of studied indicators were high and statistically significant $(\mathrm{P}<0.01)$ while the remaining values were medium to low without significance $(\mathrm{P}>0.05)$. According to Consulting Priorities indicator was a highly significant relationship with each of Public-Private Consulting, and Agricultural Cooperative Advisory. A strong relationship was found between Public-Private cooperation and Guiding Role of NGOs.

Table 2 Correlation values between agricultural and rural development, cooperative consultancy and agricultural extension for the indicators studied in Jordan

\begin{tabular}{|c|c|c|c|c|c|c|c|c|c|c|c|c|c|c|c|}
\hline Variable & TS & EAK & AKS & CP & CCW & OFC & CFC & CCS & PPC & GRN & CPI & PPO & NAS & NAC & ACA \\
\hline AS & $0.99^{* *}$ & $0.97 * *$ & $0.96^{* *}$ & $0.71^{\mathrm{ns}}$ & $0.99 * *$ & $0.98^{* *}$ & $0.97^{* *}$ & $0.86^{*}$ & $0.13^{\text {ns }}$ & $0.21^{\mathrm{ns}}$ & $0.95^{* *}$ & $0.80^{\text {ns }}$ & $0.96^{* *}$ & $0.99 * *$ & $0.81^{*}$ \\
\hline TS & & $0.94^{* *}$ & $0.94^{* *}$ & $0.79^{\text {ns }}$ & $0.98^{* *}$ & $0.97^{* *}$ & $0.95^{* *}$ & $0.91^{* *}$ & $0.14^{\text {ns }}$ & $0.21^{\mathrm{ns}}$ & $0.93^{* *}$ & $0.86^{*}$ & $0.94^{* *}$ & $0.98^{* *}$ & $0.87^{*}$ \\
\hline EAK & & & $0.99^{* *}$ & $0.55^{\mathrm{ns}}$ & $0.96^{* *}$ & $0.99^{* *}$ & $0.99 * *$ & $0.88^{*}$ & $-0.13^{n s}$ & $-0.05^{\mathrm{ns}}$ & $0.99 * *$ & $0.65^{\mathrm{ns}}$ & $0.99^{* *}$ & $0.94^{* *}$ & $0.65^{\mathrm{ns}}$ \\
\hline AKS & & & & $0.54^{\mathrm{ns}}$ & $0.96^{* *}$ & $0.99^{* *}$ & $0.99 * *$ & $0.88^{*}$ & $-0.13^{n s}$ & $-0.06^{n s}$ & $0.99^{* *}$ & $0.65^{\mathrm{ns}}$ & $0.99 * *$ & $0.94^{* *}$ & $0.65^{\text {ns }}$ \\
\hline CP & & & & & $0.70^{\mathrm{ns}}$ & $0.62^{\mathrm{ns}}$ & $0.58^{\mathrm{ns}}$ & $0.69^{\text {ns }}$ & $0.54^{\mathrm{ns}}$ & $0.59^{\mathrm{ns}}$ & $0.52^{\mathrm{ns}}$ & $0.97^{* *}$ & $0.55^{\mathrm{ns}}$ & $0.75^{\text {ns }}$ & $0.95^{* *}$ \\
\hline CCW & & & & & & $0.98^{* *}$ & $0.97^{* *}$ & $0.83^{*}$ & $0.16^{\mathrm{ns}}$ & $0.23^{\mathrm{ns}}$ & $0.95^{* *}$ & $0.78^{\mathrm{ns}}$ & $0.96^{* *}$ & $0.99 * *$ & $0.80^{*}$ \\
\hline OFC & & & & & & & $0.99 * *$ & $0.89^{*}$ & $-0.04^{\mathrm{ns}}$ & $0.04^{\mathrm{ns}}$ & $0.99^{* *}$ & $0.72^{\mathrm{ns}}$ & $0.99 * *$ & $0.97^{* *}$ & $0.72^{\mathrm{ns}}$ \\
\hline CFC & & & & & & & & $0.89^{*}$ & $-0.10^{\mathrm{ns}}$ & $-0.03^{n s}$ & $0.99 * *$ & $0.69^{\text {ns }}$ & $0.99^{* *}$ & $0.95^{* *}$ & $0.68^{\text {ns }}$ \\
\hline CCS & & & & & & & & & $-0.17^{n s}$ & $-0.10^{\mathrm{ns}}$ & $0.88^{*}$ & $0.78^{\mathrm{ns}}$ & $0.88^{*}$ & $0.83^{*}$ & $0.73^{\text {ns }}$ \\
\hline PPC & & & & & & & & & & $0.99 * *$ & $-0.17^{\mathrm{ns}}$ & $0.44^{\mathrm{ns}}$ & $-0.13^{\mathrm{ns}}$ & $0.21^{\mathrm{ns}}$ & $0.55^{\mathrm{ns}}$ \\
\hline GRN & & & & & & & & & & & $-0.09^{n s}$ & $0.50^{\mathrm{ns}}$ & $-0.05^{\mathrm{ns}}$ & $0.29^{\mathrm{ns}}$ & $0.60^{\text {ns }}$ \\
\hline CPI & & & & & & & & & & & & $0.63^{\mathrm{ns}}$ & $0.99^{* *}$ & $0.93^{*}$ & $0.63^{\text {ns }}$ \\
\hline PPO & & & & & & & & & & & & & $0.65^{\mathrm{ns}}$ & $0.82 *$ & $0.95^{* *}$ \\
\hline NAS & & & & & & & & & & & & & & $0.94^{* *}$ & $0.65^{\text {ns }}$ \\
\hline NAC & & & & & & & & & & & & & & & $0.84^{*}$ \\
\hline
\end{tabular}

AS: Agricultural Specialization, TS: Target Sectors, EAK: Extension Agricultural Knowledge, AKS: Agricultural Knowledge Source,

CP: Consulting Priorities, CCW: Cooperative Consulting Work, OFC: Obstacles Facing consulting, CFC: Challenges Facing consulting,

CCS: Collaborative Consulting Sharing, PPC: Public-Private cooperation, GRN: Guiding Role of NGOs, CPI: Consulting Policies and Insights, PPO: Public-Private Consulting, NAS: NGOs Advisory Services, NAC: NG's Advisory Categories, ACA: Agricultural Cooperative Advisory.

\section{DISCUSSIONS}

Horticulture and animal products have been among the areas of agricultural production that have received the most attention from an agricultural extension. An agricultural extension was mainly directed towards rural women and the youth sector in countryside. Most of the target sectors have high knowledge of agricultural extension, and most of them are achieved through agricultural extension visits. Burt (2004) reported that Collaborative Advisory Service aims to provide farmers with institutional guidance to improve their capacities in agricultural knowledge, farm management, marketing, and sustainable livelihood development. Cooperatives are a relevant actor for inducing more sustainable practices by providing or coordinating advisory services Snider et al. (2016). Cooperative management functions not only to contribute to the development of agriculture but also to improve quality of life of farmers Gherman et al. (2016). Most of the cooperative advisory work was carried out through agricultural plans by training agricultural extension workers and attending scientific seminars for cooperatives. The importance of collaborative consulting lies in the economic return through planning and investment in modern technology Trifan and Zeca (2017). The relationship between public and private cooperatives was regular and most of the NGO advisory services were directed at cooperatives and associations. Burt (2004) noted that the collaborative keys to success are professional advisors, communication with members, a mindset that encourages good practice and maintaining a formal board/management relationship. The existence of cooperatives also enhances institutional support and productive organizational linkages and increases farmers' 
incomes Bwabo et al. (2016). However, there are handicaps in terms of regulations and financial support and challenges such as the lack of specialized agricultural consultancy consulting agents. Collaborative emergency preparedness protects the environment USDA (2021). Plant protection, crop production, and livestock production were among the priorities of agricultural extension work, followed by water, irrigation, environment, and agricultural marketing, while agricultural cooperation ranked last. Cooperative priorities serve its members, providing services to agriculture directly (increasing net income) and indirectly (marketing power), supporting family farms and income generated in the community Burt (2004). Farmers' associations in cooperatives have many advantages by providing raw materials for timely production at low prices, reducing the risks of selling products, and opening up prospects that help simplify production Trifan and Zeca (2017). Well-functioning cooperatives can bring many benefits to their members such as pooling labour resources, providing machinery or production activities Burt (2004). The agricultural extension uses methods of field visits, agricultural advisory meetings, agricultural field consultations, and field schools for farmers on a permanent basis, while field days and agricultural advisory booklets are sometimes used, and home visits and newspapers are rarely used. Extension services should not only focus on increasing productivity, but also on improving farmers' ability to increase income as well as environmental considerations and impacts on society Amanah (2018). Cooperation between the public and private sectors (3.3\%) and the advisory role of NGOs at work is only (10\%) compared to the role of government agencies, where cooperative advisory visions and policies play a full role $(100 \%)$ in agricultural extension. cooperation. The cooperative guarantees the quantity and quality of products needed to meet market demands and thus achieve greater returns for the members. Cooperatives also directly encourage investments (Ma et al., 2018). Cooperatives that engage in marketing increase marketing margins and increase the technical competence of their members Qu et al. (2020). Supporting should take into account the marketing competence of smallholder farmers $\mathrm{Wu}$ (2012). Correlation values between most of the studied indicators were high and significant, while the remaining values were medium to low without significance. According to the consultancy, priority indicators have a very important relationship with both public and private consultancy and agricultural cooperative consultancy. In addition, a strong relationship was found between the public and private cooperation sectors and the guiding role of NGOs.

\section{CONCLUSIONS}

The agricultural extension should pay more attention to small farmers and the cooperative sector, and agricultural cooperation should be a priority for an extension. In order to overcome the challenges and obstacles of extension work, financial support must be provided for workshops, extension programs, and brochures containing technical information. Paying attention to agricultural extension cooperation methods through increasing fieldwork days, extension bulletins, home visits, and daily newspapers. Importance of consulting cooperation between governmental and NGOs in supporting farmers' projects. Collaboration between governmental and non-governmental sectors was related to both the work priorities and the advisory role of NGOs. 


\section{ACKNOWLEDGMENT}

Sincere gratitude to Jerash University for its continued support of scientific publication, and to the Jordanian Ministry of Agriculture for providing facilities with regard to data collection.

\section{REFERENCES}

Amanah, S. (2018). Cooperative Advisory Services to strengthen Capacity of Small Holder Farmers towards Sustainability, best practices notes. Faculty of Human Ecology, Bogor Agricultural University (IPB), Indonesia (rural Advisory Services for Southeast Asia). No.8.

Burt, L. (2004). A brief Introduction to Agricultural Cooperatives. Oregon State University Extension Serveries, EM 8665. Retrieved from https://ir.library.oregonstate.edu/concern/open_educational_resources / x k81jk591

Bwabo, M., Mchopa, A., and Huka, H. (2016). Agricultural Productivity, Cooperatives and Organizational Innovations : A Case of Selected Coffee Production Communities in Mbinga District Tanzania. The Open University of Tanzania. HURIA Journal, Vol. 22. Retrieved from https://www.ajol.info/index.php/huria/article/view/152643

Gherman, R., Dincu, A.M., Milin, A., and Brad, L. (2016). Agriculture and Agricultural Cooperatives in Japan - A Model for Cooperativization of Agriculture from Romania. Animal Science and Biotechnologies, 49 (2).

JCC, (Jordan Cooperative Corporation). (2021). Jordanian cooperative movement, establishment and development.

Ma, W., Renwick, A., Yuan, P., Ratna, N. (2018). Agricultural cooperative membership and technical efficiency of apple farmers in China : An analysis accounting for selectivity bias. Food Policy, 81, 122-132. Retrieved from https://doi.org/10.1016/j.foodpol.2018.10.009

McLeod, S.A. (2019). Likert scale. Simply Psychology. Retrieved from https://www.simplypsychology.org/likert-scale.html.

Qu, R., Wu, Y., Chen, J., Jones, G.D., Li, W., Jin, S., Chang, Q., Cao, Y., Yang, G., Li, Z., and Frewer L.J. (2020). Effects of Agricultural Cooperative Society on Farmers' Technical Efficiency : Evidence from Stochastic Frontier Analysis. Sustainability, 12, 8194. Doi : 10.3390/su12198194. Retrieved from https://doi.org/10.3390/su12198194

Rimawi, A., Arabiat, S. (1998). Agricultural Extension in Jordan ; A Critical review. Faculty of Agriculture, Unversity of Jordan. Published in the proceedings of the symposium, Cambridge and Edinburgh, Reading University, United Kingdom.

SAS®, (2012). SAS/stat user's guide : statistics, system for windows, version 4.10 (release 6.12 TS level 0020) SAS Inst., Inc., Cary, North Carolina, USA.

Snider, A., Kraus, E., Sibelet, N., Bosselmann, A.S., and Faure, G. (2016). Influence of Voluntary Coffee Certifications on Cooperatives' Advisory Services and Agricultural Practices of Smallholder Farmers in Costa Rica. Journal of Agricultural Education and Extension, Vol.22. No. 5. P : 435-453. Retrieved from https://doi.org/10.1080/1389224X.2016.1227418 
Trifan, D., and Zeca, E.D. (2017). The Importance of Association for Smart, Sustainable and Inclusive Development of Rural Area. Acta Universitatis Danubius. Economical, Vol. 13, No. 1.

USDA, (United States Department of Agriculture). (2021). Cooperative Extension System. National Institute of Food and Agriculture.

$\mathrm{Wu}, \mathrm{C}$. (2012). Comparative analysis of the efficiency of different modes of farmer cooperatives based on a survey of 440 sample farmers in Guangdong and Anhui Province. Agric. Econ. Issues 34, 79-86 